\title{
Kadar Hypoxia Inducible Factor-1a pada Penderita Diabetes Melitus Tipe 2 Disertai Mikroalbuminuria dan Retinopati
}

\author{
Yumilia Hoo, ${ }^{1}$ Hikmat Permana, ${ }^{2}$ Nanny Natalia M Soetedjo, ${ }^{2}$ Augusta Y. L. Arifin ${ }^{2}$ \\ ${ }^{1}$ Ilmu Penyakit Dalam, Rumah Sakit Immanuel Bandung ${ }^{2}$ Divisi Endokrinologi dan Metabolik, \\ Departemen Ilmu Penyakit Dalam Fakultas Kedokteran/Rumah Sakit Dr. Hasan Sadikin Bandung
}

\begin{abstract}
Abstrak
Diabetes melitus tipe 2 (DMT2) sampai saat ini masih menjadi masalah kesehatan karena bersifat progresif dan menimbulkan komplikasi. Menurut data epidemiologi dari International Diabetes Federation (IDF) tahun 2011, dinyatakan bahwa retinopati diabetik sering kali mendahului mikroalbuminuria. Komplikasi tersebut diawali oleh disfungsi endotel yang akan meningkatkan sekresi sitokin yang menginduksi angiogenesis dan limpangiogenesis. Pada keadaan hipoksia akibat perubahan mikrovaskular, hypoxia inducible factor-1 alpha (HIF1 $\boldsymbol{\alpha}$ ) disekresikan dan akan merangsang produksi vascular endothelial growth factor (VEGF) yang menginduksi angiogenesis. Penelitian ini bertujuan untuk mengetahui hubungan kadar HIF-1 $\boldsymbol{\alpha}$ plasma penderita DMT2 dengan mikroalbuminuria dan retinopati diabetik. Penelitian menggunakan rancangan studi potong lintang terhadap 158 penderita DMT2 yang berobat di poliklinik endokrinologi Rumah Sakit Dr. Hasan Sadikin Bandung periode Juli-Desember 2012. Data dianalisis menggunakan uji-t, Mann Whitney, dan multivariate analysis of variance (MANOVA). Subjek penelitian terdiri atas 82 orang pria $(51,9 \%)$ dan 76 orang wanita $(48,1 \%)$. Delapan puluh orang $(50,6 \%)$ normoalbuminuria dan 78 orang $(49,4 \%)$ mikroalbuminuria. Pada penelitian ini didapatkan 38 orang dengan retinopati diabetik $(24,1 \%)$. Median kadar HIF-1 $\alpha$ kelompok mikroalbuminuria adalah 0,103 $(0,041-0,735) \mathrm{ng} / \mathrm{mL}$ dan pada normoalbuminuria $0,144(0,041-0,481) \mathrm{ng} / \mathrm{mL}(\mathrm{p}=0,257)$. Median kadar HIF$1 \alpha$ kelompok retinopati positif $0,041(0,041-0,33) \mathrm{ng} / \mathrm{mL}$, sedangkan kelompok tanpa retinopati $0,167(0,041-$ $0,735) \mathrm{ng} / \mathrm{mL}$ dengan $\mathrm{p}<0,01$. Simpulan, kadar HIF-1 $\alpha$ plasma yang rendah atau normal bergantung pada derajat retinopati diabetik. Kadar HIF-1 $\alpha$ plasma yang tinggi pada penderita tanpa retinopati diabetik, menunjukkan akan terjadi retinopati diabetik di masa mendatang. [MKB. 2014;46(2):100-5]
\end{abstract}

Kata kunci: Hypoxia inducible factor-1 $\alpha$, mikroalbuminuria, retinopati diabetik

\section{Hypoxia Inducible Factor-1 $\alpha$ in Type 2 Diabetes Mellitus with Microalbuminuria and Retinopathy}

\begin{abstract}
Type 2 diabetes mellitus (T2DM) is still considered a major problem in healthcare, mainly for its progressivity and complications. According to the epidemiological data from the International Diabetes Federation (IDF) in 2011, it is stated that microalbuminuria often precedes the onset of diabetic retinopathy. Complications are preceded by endothelial dysfunction that will increase the secretion of cytokines inducing angiogenesis and limpangiogenesis. In hypoxic conditions induced by microvascular changes, hypoxia inducible factor-1 alpha (HIF-1 $\boldsymbol{\alpha}$ ) is secreted, stimulating the production of vascular endothelial growth factor (VEGF) which induce angiogenesis. The aim of this study was to know the correlation between plasma HIF-1 $\alpha$ concentration with microalbuminuria pattern and diabetic retinopathy in T2DM patients. This cross-sectional study was conducted on 158 T2DM patients in Endocrinology Outpatient Departement of Dr. Hasan Sadikin Hospital during July to December 2012. Data were analyzed using t-test, Mann Whitney, and multivariate analysis of variance (MANOVA) methods. Eighty two males $(51.9 \%)$ and 76 females $(48.1 \%)$ participated in the study, making up 158 subjects. Eighty patients $(50.6 \%)$ had normoalbuminuria and 78 patients $(49.4 \%)$ had microalbuminuria. Thirty eight patients were found with diabetic retinopathy $(24.1 \%)$. The median of HIF-1 $\boldsymbol{\alpha}$ plasma concentrations was $0.103(0.041-0.735) \mathrm{ng} / \mathrm{mL}$ in the microalbuminuria group and $0.144(0.041-0.481) \mathrm{ng} / \mathrm{mL}(\mathrm{p}=0.257)$.in the normoalbuminuria group. The median of HIF-1 $\boldsymbol{\alpha}$ plasma concentration in the group with diabetic retinopathy was $0.041(0.041-0.33) \mathrm{ng} / \mathrm{mL}$, while in the group without diabetic retinopathy the median was $0.167(0.041-0.735) \mathrm{ng} / \mathrm{mL}(\mathrm{p}<0.01)$. In conclusion, low or normal HIF-1 $\boldsymbol{\alpha}$ plasma levels in patients without diabetic retinopathy predict the grading of diabetic retinopathy, while high levels of plasma HIF-1 $\boldsymbol{\alpha}$ suggests the likehood of retinopathy event in the future. [MKB. 2014;46(2):100-5]
\end{abstract}

Key words: Diabetic retinopathy, hypoxia inducible factor-1 $\alpha$, microalbuminuria

Korespondensi: Yumilia Hoo, dr., Sp.PD, Sekretariat Ilmu Penyakit Dalam, Rumah Sakit Immanuel Jalan Kopo No.161 Bandung 40234, mobile 08122315550,e-mail yumiliahoo@yahoo.co.id 


\section{Pendahuluan}

Diabetes melitus tipe 2 (DMT2) sampai saat ini masih menjadi masalah karena bersifat progresif dan prevalensinya terus meningkat. Progresivitas DMT2 menyebabkan berbagai komplikasi yang pada umumnya berhubungan dengan vaskulopati antara lain misal nefropati diabetik yang ditandai dengan mikroalbuminuria dan retinopati diabetik. Menurut data epidemiologi International Diabetes Federation (IDF) tahun 2011, dinyatakan bahwa retinopati diabetik sering mendahului terjadinya mikroalbuminuria. ${ }^{1}$

Retinopati diabetik menyebabkan kebutaan sebanyak $12 \%$ per tahun pada usia 20-74 tahun di negara berkembang dan dapat meningkatkan biaya kesehatan dan juga menurunkan kualitas hidup penderita DM. Klein ${ }^{2}$ menyatakan bahwa retinopati diabetik dapat terjadi $33 \%$ dalam 5 tahun setelah diagnosis diabetes melitus (DM) ditegakkan dan prevalensinya akan meningkat menjadi $80 \%$ pada 20 tahun kemudian. Insidensi retinopati diabetik bergantung pada lama diabetes melitus diderita. Hal tersebut juga ditemukan pada komplikasi vaskulopati yang lain yaitu nefropati diabetik. Sebanyak 20\% penderita DMT2 akan berkembang menjadi gagal ginjal terminal dalam waktu 5 sampai 25 tahun. Nefropati diabetik pada stadium dini ditandai dengan mikroalbuminuria.

Mikroalbuminuria adalah gambaran ekskresi albumin berlebihan yang dikeluarkan melalui urin akibat penurunan fungsi ginjal. Komplikasi dari retinopati diabetik dan mikroalbuminuria itu dipengaruhi oleh banyak faktor. Komplikasi tersebut diawali dengan disfungsi endotel yang disebabkan oleh hiperglikemia, hiperinsulinemia, hipertensi, dislipidemia, dan obesitas. ${ }^{3,4}$ Disfungsi endotel akan dapat meningkatkan sekresi sitokin, salah satunya yaitu vascular endothelial growth factor (VEGF) yang menginduksi angiogenesis. Pada keadaan hipoksia yang diakibatkan karena perubahan dari mikrovaskular, hypoxia inducible factor-1 $\alpha$ (HIF-1 $\alpha)$ yang disekresikan dan akan merangsang produksi VEGF dan nitric oxide (NO). Kadar HIF-1 $\alpha$ juga akan meningkatkan kadar NO yang ternyata bersifat vasodilatasi. Pada retinopati diabetik, keadaan ini akan menstimulasi angiogenesis, meningkatkan permeabilitas yang menyebabkan kerusakan barier pembuluh darah, perdarahan vitreous, dan fibrosis. Pada nefropati diabetik dapat terjadi proliferasi sel abnormal, angiogenesis, peningkatan produksi matriks, dan apoptosis. $^{3}$

Penelitian ini bertujuan untuk memperlihatkan hubungan kadar HIF-1 $\alpha$ dengan mikroalbuminuria dan retinopati diabetik pada penderita diabetes melitus tipe 2 (DMT2).

\section{Metode}

Penelitian ini merupakan suatu studi epidemiologi klinik dengan metode potong lintang. Subjek penelitian ini adalah penderita DMT2. Kriteria eksklusi yaitu penderita diabetes melitus tipe 1 atau tipe lain dan yang mempunyai penyakit ginjal lain. Penelitian ini dilakukan periode Juli-Desember 2012 di poliklinik endokrinologi Rumah Sakit Dr. Hasan Sadikin Bandung. Data dianalisis menggunakan uji-t, Mann Whitney, dan multivariate analysis of variance (MANOVA).

\section{Hasil}

Subjek penelitian secara keseluruhan 158 orang berusia 38-83 tahun, terdiri atas 82 orang pria $(51,9 \%)$ dan 76 orang wanita $(48,1 \%)$ dengan lama menderita diabetes $>5$ tahun, median 9 tahun (525) tahun. Subjek penelitian terdiri atas 78 orang dengan mikroalbuminuria (49,4\%) dan 80 orang dengan normoalbuminuria (50,6\%). Didapatkan 38 orang dengan retinopati diabetik $(24,1 \%)$ dan sebanyak 120 orang tanpa retinopati diabetik (75,9\%), sebanyak 19 penderita retinopati diabetik pada kelompok normoalbuminuria 23,7\% dan 19 orang pada kelompok mikroalbuminuria $(24,4 \%)$. Karakteristik subjek penelitian ini berdasarkan mikroalbuminuria dan retinopati dapat dilihat pada Tabel 1 dan 2 .

Berdasarkan analisis multivariate analysis of variance (MANOVA) terdapat pengaruh besaran lingkaran pinggang terhadap mikroalbuminuria $(\mathrm{p}=0,002)$. Pengaruh lingkaran pinggang pada mikroalbuminuria yang bermakna menunjukkan semakin meningkat besaran lingkaran pinggang berpengaruh pada mikroalbuminuria. Pengaruh bermakna pada mikroalbuminuria dan interaksi mikroalbuminuria-retinopati adalah kadar gula darah 2 (dua) jam setelah makan $(\mathrm{p}=0,000$ dan $\mathrm{p}=0,020$ ). Hal ini menunjukkan semakin tinggi kadar gula darah 2 (dua) jam setelah makan, akan semakin berpengaruh terhadap mikroalbuminuria dan interaksi mikroalbuminuria serta retinopati. Terhadap retinopati sendiri kadar gula darah 2 (dua) jam setelah makan tidak berpengaruh yang bermakna $(p=0,089)$. Kadar HbAlc terhadap mikroalbuminuria, retinopati, dan juga interaksi mikroalbuminuria memiliki $\mathrm{p}=0,022 ; \mathrm{p}=0,021$; dan $p=0,444$. Hal ini menunjukkan pengaruh kadar $\mathrm{HbAlc}$ terhadap mikroalbuminuria dan retinopati diabetik. Semakin tinggi kadar $\mathrm{HbA1c}$, maka akan berpengaruh pada mikroalbuminuria dan juga retinopati, sedangkan pada interaksi mikroalbuminuria-retinopati tidak menunjukkan 
Tabel 1 Karakteristik Subjek Penelitian Mikroalbuminuria

\begin{tabular}{|c|c|c|c|c|c|}
\hline & \multicolumn{2}{|c|}{ Mikroalbuminuria } & \multicolumn{2}{|c|}{ Normoalbuminuria } & \multirow[b]{2}{*}{ p } \\
\hline & $\begin{array}{r}\text { Mean } \\
\text { (SD) } \\
\end{array}$ & $\begin{array}{c}\text { Median } \\
\text { (Min-Maks) } \\
\end{array}$ & $\begin{array}{c}\text { Mean } \\
\text { (SD) }\end{array}$ & $\begin{array}{c}\text { Median } \\
\text { (Min-Maks) } \\
\end{array}$ & \\
\hline Usia (tahun) & & $63(45-83)$ & & $64,5(38-80)$ & $0,742^{\mathrm{b}}$ \\
\hline Lama DM (tahun) & & $10(5-25)$ & & $9(5-20)$ & $0,675^{\mathrm{b}}$ \\
\hline IMT $(\mathrm{kg} / \mathrm{cm})$ & $24,80(3,77)$ & & $24,35(3,57)$ & & $0,432^{\mathrm{a}}$ \\
\hline $\begin{array}{l}\text { Lingkar pinggang } \\
(\mathrm{cm})\end{array}$ & $87,68(9,60)$ & & $83,79(9,63)$ & & $0,012^{\mathrm{a}}$ \\
\hline $\begin{array}{l}\text { Lingkar pinggul } \\
(\mathrm{cm})\end{array}$ & $97,60(8,53)$ & & $95,66(8,49)$ & & $0,154^{\mathrm{a}}$ \\
\hline TD sistol (mmHg) & & $130(100-170)$ & & $120(90-160)$ & $0,007^{\mathrm{b}}$ \\
\hline TD diastol (mmHg) & & $80(60-120)$ & & $80(60-100)$ & $0,154^{\mathrm{b}}$ \\
\hline GDP (mg/dL) & & $144(51-385)$ & & $125(82-262)$ & $0,024^{\mathrm{b}}$ \\
\hline GD2PP (mg/dL) & & 204,5 (118-447) & & $175(51-345)$ & $0,005^{\mathrm{b}}$ \\
\hline HbA1c (\%) & & $8,05(5,5-13,4)$ & & $7,15(4,8-12,1)$ & $0,017^{\mathrm{b}}$ \\
\hline $\begin{array}{l}\text { Kolesterol total } \\
(\mathrm{mg} / \mathrm{dL})\end{array}$ & $190,41(37,60)$ & & $191,39(34,01)$ & & $0,864^{\mathrm{a}}$ \\
\hline $\begin{array}{l}\text { Kolesterol HDL } \\
(\mathrm{mg} / \mathrm{dL})\end{array}$ & & $45(24-80)$ & & $49(30-97)$ & $0,057^{\mathrm{b}}$ \\
\hline $\begin{array}{l}\text { Kolesterol LDL } \\
(\mathrm{mg} / \mathrm{dL}\end{array}$ & $116,94(30,16)$ & & $116,83(29,88)$ & & $0,982^{\mathrm{a}}$ \\
\hline Trigliserida $(\mathrm{mg} / \mathrm{dL})$ & & $133(49-450)$ & & $110,5(49-340)$ & $0,189^{b}$ \\
\hline HIF (ng/mL) & & $0,103(0,041-0,735)$ & & $0,144(0,041-0,481)$ & $0,257^{\mathrm{b}}$ \\
\hline
\end{tabular}

pengaruh yang bermakna

Pengaruh variabel tekanan darah sistol pada mikroalbuminuria, retinopati, dan juga interaksi mikroalbuminuria-retinopati memiliki $\mathrm{p}=0,023$; $\mathrm{p}=0,874$; dan $\mathrm{p}=0,956$. Keadaan ini menunjukkan bahwa semakin meningkat tekanan darah sistol akan memiliki pengaruh pada mikroalbuminuria, sedangkan terhadap interaksi mikroalbuminuriaretinopati dan juga retinopati tidak menunjukkan pengaruh yang bermakna.

\section{Pembahasan}

Padapenelitianinididapatkan38(24,1\%)penderita dengan retinopati diabetik, $19(23,7 \%)$ orang kelompok normoalbuminuria dan 19 (24,4\%) orang kelompok mikroalbuminuria. Penelitian yang dilakukan oleh An dkk. ${ }^{5}$ menunjukkan bahwa retinopati diabetik terdapat pada sebanyak $28 \%$ penderita DMT2 dengan mikroalbuminuria. Manaviat dkk. ${ }^{6}$ menemukan bahwa retinopati diabetik terdapat pada $27,6 \%$ penderita DMT2 dengan normoalbuminuria dan $43,35 \%$ penderita DMT2 dengan mikroalbuminuria.

Karakteristik umum subjek penelitian ini menunjukkan bahwa indeks massa tubuh (IMT) rata-rata $24,6 \pm 3,7 \mathrm{~kg} / \mathrm{m}^{2}$ (overweight dan obese), dengan median kadar gula darah puasa 138 (51$385) \mathrm{mg} / \mathrm{dL}$ dan kadar gula darah 2 jam setelah makan rata-rata $195,7 \pm 61,7 \mathrm{mg} / \mathrm{dL}$, median HbA1c 7,6 $(4,8-13,4)$ yang menunjukkan kontrol glikemik yang kurang baik dan lingkar pinggang rata rata $85,7 \pm 9,7 \mathrm{~cm}$.

Pada penelitian didapatkan perbedaan yang bermakna lingkar pinggang, tekanan darah sistol, kadar gula darah puasa, gula darah 2 (dua) jam setelah makan dan kadar HbA1c pada kelompok mikroalbuminuria. PERKENI ${ }^{7}$ membuat kriteria sebagai berikut: IMT normal adalah 18,5-22,9 $\mathrm{kg} / \mathrm{m}^{2}$, berlebih jika IMT $\geq 23,0 \mathrm{~kg} / \mathrm{m}^{2}$, dengan risiko bila IMT 23-24,9 $\mathrm{kg} / \mathrm{m}^{2}$, obese 1 IMT $25-$ $29,9 \mathrm{~kg} / \mathrm{m}^{2}$, dan obese II IMT $>30 \mathrm{~kg} / \mathrm{m}^{2}$. Pada penelitian ini IMT kelompok mikroalbuminuria rata rata $24,80 \pm 3,77 \mathrm{~kg} / \mathrm{m}^{2}$ (termasuk normal sampai obese 1). Penderita dikatakan memiliki obesitas sentral bila lingkar pinggang $\geq 90 \mathrm{~cm}$ untuk laki laki dan $\geq 80 \mathrm{~cm}$ untuk perempuan. Pada penelitian ini lingkar pinggang kelompok mikroalbuminuria $87,68 \pm 9,60 \mathrm{~cm}$, sedangkan kelompok normoalbuminuria sebesar $87,79 \pm 9,63$ $\mathrm{cm}$. Pada penelitian yang dilakukan sebelumnya 
Tabel 2 Karakteristik Subjek Penelitian Mikroalbuminuria

\begin{tabular}{|c|c|c|c|c|c|}
\hline & \multicolumn{2}{|c|}{ Retinopati (+) } & \multicolumn{2}{|c|}{ Retinopati (-) } & \multirow[b]{2}{*}{$\mathbf{p}$} \\
\hline & $\begin{array}{c}\text { Mean } \\
\text { (SD) }\end{array}$ & $\begin{array}{c}\text { Median } \\
\text { (Min-Maks) }\end{array}$ & $\begin{array}{l}\text { Mean } \\
\text { SD) }\end{array}$ & $\begin{array}{c}\text { Median } \\
\text { (Min-Maks) }\end{array}$ & \\
\hline Usia (tahun) & $60,97(9,10)$ & & $64,38(7,22)$ & & $0,040^{\mathrm{a}}$ \\
\hline Lama DM (tahun) & & $10(5-25)$ & & $9(5-19)$ & $0,173^{\mathrm{b}}$ \\
\hline IMT (kg/cm) & $24,31(3,41)$ & & $24,66(3,75)$ & & $0,609^{\mathrm{a}}$ \\
\hline $\begin{array}{l}\text { Lingkar pinggang } \\
(\mathrm{cm})\end{array}$ & $85,50(10,63)$ & & $85,78(9,55)$ & & $0,881^{\mathrm{a}}$ \\
\hline $\begin{array}{l}\text { Lingkar pinggul } \\
(\mathrm{cm})\end{array}$ & $96,29(9,61)$ & & $96,73(8,21)$ & & $0,785^{\mathrm{a}}$ \\
\hline TD sistol (mmHg) & & $130(100-150)$ & & $130(90-170)$ & $0,993^{b}$ \\
\hline TD diastol (mmHg) & & $80(70-100)$ & & $80(60-120)$ & $0,834^{b}$ \\
\hline GDP (mg/dL) & & $155,5(89-322)$ & & $131(51-385)$ & $0,006^{\mathrm{b}}$ \\
\hline GD2PP (mg/dL) & & $202,5(78-447)$ & & $190,5(51-332)$ & $0,568^{b}$ \\
\hline HbAlc (\%) & & $8,4(4,8-13,4)$ & & $7,4(5,5-12,5)$ & $0,012^{b}$ \\
\hline $\begin{array}{l}\text { Kolesterol Total } \\
(\mathrm{mg} / \mathrm{dL})\end{array}$ & $192,97(37,93)$ & & $190,25(35,12)$ & & $0,683^{\mathrm{a}}$ \\
\hline $\begin{array}{l}\text { Kolesterol HDL } \\
(\mathrm{mg} / \mathrm{dL})\end{array}$ & & 48,5 (31-97) & & $47(24-79)$ & $0,172^{b}$ \\
\hline $\begin{array}{l}\text { Kolesterol LDL } \\
(\mathrm{mg} / \mathrm{dL})\end{array}$ & $118,13(35,14)$ & & $116,48(28,22)$ & & $0,793^{\mathrm{a}}$ \\
\hline $\begin{array}{l}\text { Trigliserida } \\
(\mathrm{mg} / \mathrm{dL})\end{array}$ & & $105(49-238)$ & & $127(49-450)$ & $0,100^{\mathrm{b}}$ \\
\hline HIF (ng/mL) & & $0,041(0,041-0,33)$ & & $0,167(0,041-0,735)$ & $<0,01^{\mathrm{b}}$ \\
\hline
\end{tabular}

menunjukkan bahwa obesitas merupakan faktor risiko untuk terjadi komplikasi mikrovaskular pada diabetes melitus. ${ }^{8}$ Penelitian yang dilakukan oleh de Jongh dkk. ${ }^{9}$ menunjukkan bahwa obesitas ditandai dengan disfungsi mikrovaskular yang berhubungan dengan peningkatan tekanan darah dan berkurangnya sensitivitas terhadap insulin.

Indeks massa tubuh (IMT) rata-rata pada kelompok mikroalbuminuria sebesar 24,80 $\pm 3,77$ $\mathrm{kg} / \mathrm{m}^{2}$ dan normoalbuminuria sebesar $24,35 \pm 3,57$ $\mathrm{kg} / \mathrm{m}^{2}$, hal ini sesuai dengan kriteria overweight, tidak didapatkan obesitas morbid. Pada penelitian ini yang mempunyai peranan bukan IMT tetapi lingkar pinggang penderita.

Pada penelitian ini didapatkan kadar gula darah puasa memengaruhi kejadian mikroalbuminuria dan retinopati. Kadar gula darah puasa yang tinggi serta berlangsung kronis akan mampu menyebabkan mikroalbuminuria yang didukung oleh penelitian ini, bahwa kadar gula darah puasa pada kelompok mikroalbuminuria lebih tinggi bila dibandingkan kelompok normoalbuminuria dengan uji-t $(p=0,024)$. Hal ini dapat dijelaskan bahwa kejadian mikroalbuminuria dipengaruhi oleh faktor hemodinamik dan metabolik. Pada keadaan kadar gula darah puasa tinggi, kadar gula darah endogen akibat proses glukoneogenesis yang meningkat. Populasi penelitian merupakan subjek penderita dengan resistensi insulin yaitu penderita dengan DMT2. Keadaaan peningkatan kadar gula darah puasa akan menyebabkan injury terhadap glomerulus sehingga terjadi pendataran podosit (membran basalis) dan juga kerusakan membran basalis yang akan dapat menyebabkan kebocoran albumin. Berdasarkan uji MANOVA kadar gula darah puasa berhubungan dengan mikroalbuminuria $(p=0,020)$. Kadar gula darah puasajugaberhubungan dengan retinopati diabetik $(p=0,002)$ akan tetapi tidak berhubungan yang bermakna dengan interaksi mikroalbuminuria dan retinopati $(p=0,392)$. Hal ini menunjukkan bahwa semakin tinggi kadar gula darah berpengaruh terhadap mikroalbuminuria dan juga retinopati, sedangkan terhadap interaksi mikroalbuminuria dan retinopati tidak menunjukkan pengaruh yang bermakna.

Pada penelitian ini kadar gula darah puasa berhubungandenganhiperglikemiakronik terbukti dengan didapatkannya kadar HbA1c yang tinggi. Kadar HbA1c pada kelompok mikroalbuminuria 
lebih tinggi bermakna bila dibandingkan dengan kelompok normoalbuminuria $(\mathrm{p}=0,017)$ dan kadar HbAlc kelompok retinopati juga lebih tinggi dibandingkan dengan tanpa retinopati $(\mathrm{p}=0,012)$. Keadaan ini menunjukkan hiperglikemia kronik pada subjek penelitian. Hal ini sesuai dengan penelitian sebelumnya yang menunjukkan bahwa kontrol glikemik berhubungan dengan komplikasi mikrovaskular. ${ }^{10}$

Kadar gula darah 2 (dua) jam setelah makan memberikan pengaruh pada mikroalbuminuria dan interaksi mikroalbuminuria dengan retinopati diabetik (masing-masing $\mathrm{p}=0,000$ dan $\mathrm{p}=0,020$ ) terhadap retinopati tidak memberikan pengaruh bermakna $(p=0,089)$. Kadar gula darah lebih dari $200 \mathrm{mg} / \mathrm{dL}$ dihubungkan dengan perkembangan komplikasi ke ginjal, tidak bergantung pada kadar $\mathrm{HbA} 1 \mathrm{c}$ dan gula darah puasa. Penelitian Stratton dkk. ${ }^{11}$ memperlihatkan kadar gula darah setelah makan 148-199 mg/dL tidak hanya berisiko terjadi aterosklerosis, tetapi juga memengaruhi sel endotel arteriolar dan dihubungkan dengan meningkatnya kejadian risiko nefropati serta retinopati. Pada kadar gula darah rata-rata 200 $\mathrm{mg} / \mathrm{dL}$, risiko nefropati akan meningkat 10 kali lipat.

Pada retinopati diabetik, selain kadar gula darah puasa yang memperlihatkan pengaruh yang bermakna, ternyata kadar HIF-1 $\alpha$ juga memiliki pengaruh pada retinopati diabetik $(\mathrm{p}=0,000)$, sedangkan pada mikroalbuminuria dan interaksi mikroalbuminuria-retinopati tidak berpengaruh secara bermakna $(p=0,449$ dan $p=0,750)$. Keadaan hiperglikemia dan hipoksia berperan penting terhadap komplikasi diabetik akibat rusaknya respons jaringan terhadap tekanan oksigen yang rendah. Di dalam fibroblas dermal primer dan sel endotel, hiperglikemia mengganggu fungsi HIF$1 \alpha$ sebagai suatu faktor transkripsi yang penting untuk respons adaptif sel hipoksia. Penelitian yang mempergunakan proteosomal dan prolil inhibitor hidroksilase menunjukan hiperglikemia dapat menghambat HIF-1 $\alpha$ untuk melakukan degradasi dan juga melibatkan mekanisme selain hidroksilase prolin. ${ }^{12}$ Kadar HbA1c yang tinggi menunjukkan paparan glikemik yang merupakan faktor dominan yang dihubungkan dengan progresi retinopati. ${ }^{13}$

Komplikasi vaskulopati yang terjadi pada penderita DMT2 diawali oleh disfungsi endotel yang merusak pembuluh darah melalui berbagai sitokin termasuk faktor pertumbuhan (VEGF) yang akan menginduksi angiogenesis. Keadaan hipoksia akibat perubahan mikrovaskular akan meningkatkan produksi HIF-1 $\alpha$ dan merangsang produksi VEGF dan NO. Pada penelitian ini kadar HIF-1 $\alpha$ lebih rendah pada kelompok penderita dengan retinopati, diduga sudah terjadi kerusakan pada pembuluh darah, dan proses angiogenesis sudah tidak terjadi lagi akibat disfungsi endotel yang lama. Pada retina yang masih dalam keadaan iskemik, kadar HIF-1 $\alpha$ akan merangsang produksi VEGF dan NO. Hipoksia ini juga diketahui dapat meningkatkan berbagai mediator inflamasi yang akan menstimulasi angiogenesis, meningkatkan permeabilitas yang akan merusak barier pembuluh darah, perdarahan vitreous, dan fibrosis. ${ }^{14}$ Pada retinopati yang terjadi sudah lanjut diduga proses stimulasi angiogenesis sudah tidak terjadi lagi dan sudah terjadi kerusakan pembuluh darah di mata sehingga menyebabkan kadar HIF-1 $\alpha$ yang lebih rendah dibandingkan dengan kelompok tanpa retinopati. Falcao dkk. ${ }^{15}$ menyatakan bahwa pada mata yang sudah terjadi retinopati diabetik, terjadi kematian sel kontraktil mikrovaskular (sel perisit) yang akan dapat memicu apoptosis. Kematian perisit dan hilangnya kontak vaskular intraselular dapat menyebabkan proliferasi sel endotel yang akan memfasilitasi berkembangnya mikroaneurisma dan juga dilatasi kapiler retina. Hilangnya perisit akan menyebabkan apoptosis sel endotel kapiler dan juga hilangnya elemen sel vaskular retina serta akan menutup kapiler, akibatnya HIF-1 $\alpha$ sudah tidak dikeluarkan oleh sel endotel. Pada penelitian ini median kadar HIF-1 $\alpha$ tidak menunjukkan perbedaan bermakna antara kelompok mikroalbuminuria dan kelompok normoalbuminuria. Keadaan ini kemungkinan disebabkan karena pengaruh obat antihipertensi yang diminum oleh penderita seperti golongan angiotensin-converting-enzyme-inhibitor (ACEI) dan angiotensin II receptor antagonist (ARB). Pada kelompok penelitian ini didapatkan sebanyak 36 orang $(22,8 \%)$ dalam terapi ACEI dan sebanyak 15 orang $(9,5 \%)$ dalam terapi ARB. Mikroalbuminuria dipengaruhi oleh faktor lain yaitu faktor metabolik seperti hiperglikemia dan faktor hemodinamik di antaranya hipertensi yang dipengaruhi oleh renin-angiotensin-aldosterone system (RAAS).

Tekanan darah sistol dan diastol, kolesterol total, kolesterol high-density lipoprotein (HDL) dan low density lipoprotein (LDL), trigliserida, dan juga variabel lain pada penderita retinopati tidak berbeda bermakna. Hal ini menunjukkan bahwa pada retinopati yang berperan hanyalah proses hipoksia. Kepentingan terjadi dislipidemia pada retinopati diabetik belum dapat dibuktikan secara penuh, akan tetapi kadar lipid darah yang abnormal dihubungkan dengan berkembangnya hard exudate pada retinopati diabetik.

Pada penelitian didapatkan hasil serendipity kadar HIF-1 $\alpha$ rata-rata sesuai dengan derajat beratnya retinopati diabetik ini. Pada kelompok tanpa retinopati $0,176 \pm 0,134 \mathrm{ng} / \mathrm{mL}$, retinopati ringan $0,009 \pm 0,0965 \mathrm{ng} / \mathrm{mL}$, dan retinopati berat 
0,098 $\pm 0,1088 \mathrm{ng} / \mathrm{mL}$. Hal ini menggambarkan bahwa pada kelompok diabetes tanpa retinopati terdapat peningkatan kadar HIF-1 $\alpha$, sedangkan pada retinopati yang kejadiannya sudah lanjut kadar HIF-1 $\alpha$ rata-rata lebih tinggi dibandingkan dengan kelompok retinopati ringan. Gambaran ini memperlihatkan variabilitas rata-rata kadar HIF-1 $\alpha$, pada kelompok tanpa retinopati terjadi peningkatan, kemudian terjadi penurunan pada kelompok retinopati ringan, dan akhirnya terjadi peningkatan kembali pada retinopati yang lanjut. Hal ini memperlihatkan bahwa pada penderita DMT2 tanpa retinopati yang disertai kadar HIF$1 \alpha$ tinggi terjadi mekanisme kompensasi pada keadaan iskemia organ retina tanpa mekanisme pembentukan angiogenesis.

Pada keadaan retinopati ringan, angiogenesis sudah terbentuk dan kadar HIF-1 $\alpha$ yang menurun, akan terjadi peningkatan kadar HIF-1 $\alpha$ pada retinopati lanjut walaupun kadarnya lebih rendah apabila dibandingkan dengan tanpa retinopati. Hal ini terjadi akibat proses iskemia yang terus berlangsung sampai keadaan retinopati lanjut. Hasil ini menunjukkan bahwa terdapat suatu fase kadar HIF-1 $\alpha$ yang menurun akan meningkat kembali. Keadaan ini menggambarkan proses progresivitas kerusakan pada retina.

Simpulan, kadar HIF-1 $\alpha$ plasma yang tinggi pada penderita tanpa retinopati diabetik, menunjukkan akan terjadi retinopati diabetik di masa yang akan datang. Kadar HIF-1 $\alpha$ plasma yang rendah atau normal bergantung pada derajat retinopati diabetik. Kadar HIF-1 $\alpha$ tidak memiliki hubungan dengan mikroalbuminuria dan interaksi secara bersama mikroalbuminuria dengan retinopati.

\section{Daftar Pustaka}

1. Whiting DR, Guariguata L, Weil C, Shaw J. IDF diabetes atlas: global estimates of the prevalence of diabetes for 2011 and 2030. Diabetes Res Clin Pract. 2011;94(3):311-21.

2. Klein R. Epidemiology of diabetic retinopathy. Dalam: Duh E, penyunting. Diabetic retinopathy. Boston: Hiuma Press; 2008. hlm. 67-108.

3. Hadi HA, Suwaidi JA. Endothelial dysfunction in diabetes mellitus. Vasc Health Risk Manag. 2007;3(6):853-76.

4. Tabit CE, Chung WB, Hamburg NM, Vita JA. Endothelial dysfunction in diabetes mellitus: molecular mechanisms and clinical implications. Rev Endocr Metab Disord. 2010;11(1):61-74.
5. An JH, Cho YM, Yu HG, Jang HC, Park KS, Kim SY, dkk. The clinical characteristics of normoalbuminuric renal insufficiency in Korean type 2 diabetic patients: a possible early stage renal complication. J Korean Med Sci. 2009;24 Suppl:S75-81.

6. Manaviat MR, Afkhami M, Shoja MR. Retinopathy and microalbuminuria in type 2 diabetic patients. Int J Endocrinol Metab 2005;3(4):153-7.

7. Perkumpulan Endokrinologi Indonesia (PERKENI). Konsensus penatalaksanaan diabetes melitus. Jakarta, Indonesia: Perkeni; 2011.

8. De Boer MP, Meijer RI, Wijnstok NJ, Jonk AM, Houben AJ, Stehouwer CD, dkk. Microvascular dysfunction: a potential mechanism in the pathogenesis of obesityassociated insulin resistance and hypertension. Microcirculation. 2011;19(1):5-18.

9. de Jongh RT, Serne EH, Ijzerman RG, de Vries G, Stehouwer CD. Impaired microvascular function in obesity: implications for obesityassociated microangiopathy, hypertension, and insulin resistance. Circulation. 2004;109 (21):2529-35.

10. Fowler MJ. Microvascular and macrovascular complications of diabetes. Clinic Diabetes. 2008;26(2):77-82.

11. Stratton IM, Adler AI, Neil HA, Matthews DR, Manley SE, Cuel CA, dkk. Association of glycemia with macrovascular and microvascular complication of type 2 diabetes (UKPDS 35): prospective observational study. BMJ. 2000;321(7258):405-12.

12. Catrina SB, Okamoto K, Pereira T, Brismar $\mathrm{K}$, Poellinger L. Hyperglycemia regulates hypoxia-inducible factor-1 alpha protein stability and function. Diabetes. 2004;53(12): 3226-32.

13. Longo-Mbenza B, Muaka MM, Mbenza G, Mbungu Fuele S, Mabwa-Mbalanda L, Nzuzi-Babeki V, dkk. Risk factors of poor control of $\mathrm{HbA1C}$ and diabetic retinopathy: Paradox with insulin therapy and high values of HDL in African diabetic patients. Int $\mathrm{J}$ Diabetes \& Metabolism. 2008;16:69-78.

14. Ke Q, Costa M. Hypoxia-inducible factor-1 (HIF-1). Mol Pharmacol. 2006;70(5):146980.

15. Falcao M, Falcao-Reis F, Rocha-Sousa A. Diabetic retinopathy: understanding pathologic angiogenesis and exploring its treatment options. Open Circulation Vascular J. 2010;3:30-42. 